\title{
Transformation of Acute Myeloid Leukemia with Deletion of Chromosome 7q and Additional Abnormalities in Chromosome 8 in a Patient with Essential Thrombocythemia
}

\author{
Ayaka Shimizu $^{a}$ Kei Takenaka ${ }^{a}$ Shinya Ohata ${ }^{a}$ Kazuhide Morimotob \\ Hiromi Hashimoto $^{b}$ Yuki Yamamoto $^{c}$ Toshio Itoh $^{d}$ Takeshi Sugimoto ${ }^{a}$ \\ ${ }^{a}$ Department of Hematology/Oncology, Kita-Harima Medical Center, Ono, Japan; ${ }^{b}$ Division \\ of Clinical Laboratory, Kita-Harima Medical Center, Ono, Japan; 'Department of Diagnostic \\ Pathology, Kita-Harima Medical Center, Ono, Japan; ${ }^{\mathrm{d} D e p a r t m e n t ~ o f ~ I n t e r n a l ~ M e d i c i n e, ~}$ \\ Miki-Sanyo Hospital, Miki, Japan
}

\section{Keywords}

Acute myeloid leukemia $\cdot$ Deletion of chromosome $7 q \cdot$ Essential thrombocythemia

\section{Abstract}

This is a case report of a 60-year-old male patient with essential thrombocythemia (ET) that progressed to acute myeloid leukemia (AML) in approximately 9 years. His platelet count decreased approximately 8 years after ET treatment with hydroxyurea $(\mathrm{HU})$ and aspirin. The dose of $\mathrm{HU}$ was reduced because of suspected myelosuppression due to $\mathrm{HU}$; however, myelosuppression did not improve. Bone marrow examination revealed myelofibrosis; therefore, ruxolitinib was administered. Approximately 1 year later, his leukocyte and blast counts in the peripheral blood increased; thus, ET was judged to have progressed to AML-myelodysplasiarelated change. Induction chemotherapy and consolidation therapy were initiated; however, the patient unfortunately failed to achieve complete remission. We then continued to administer salvage chemotherapy; however, his general condition worsened, and he died from cerebral hemorrhage. The karyotype at the onset of ET was 46,XY, which changed to $47, \mathrm{XY}$, del(7q), +8 at the time of AML diagnosis. In addition, genetic testing revealed FLT-3 ITD mutation. His histopathological analysis showed subarachnoid and intraparenchymal hemorrhages and tumor cell infiltration into the cerebrum, brainstem, and cerebellum. In this case, deletion of the long arm of chromosome 7, additional abnormalities in chromosome 8, and FLT3-ITD mutation were confirmed as risk factors for having developed secondary AML for approximately 9 years and death from cerebral hemorrhage 1 year later.

\section{Karger"}



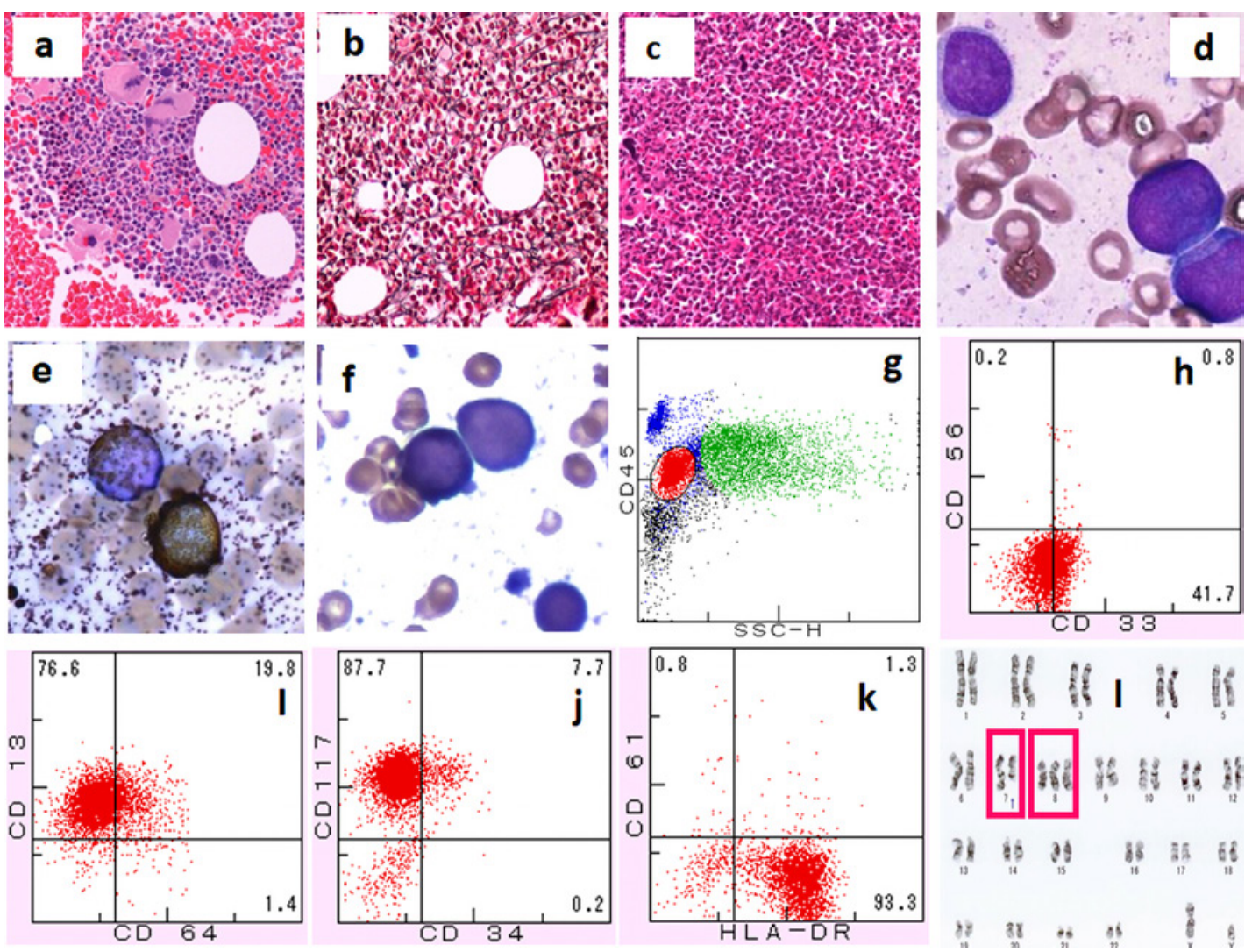

Fig. 1. Findings of bone marrow tests at the times of diagnosis of essential thrombocythemia (ET), myelofibrosis (MF), and acute myeloid leukemia (AML) and chromosomal aberrations at the time of AML diagnosis. a-c Bone marrow biopsy. a ET. b MF. c AML. d-f Bone marrow smear of AML. g-k Flow cytometry analysis of bone marrow samples of AML. I G-band analysis of bone marrow samples of AML.

\section{Introduction}

In essential thrombocythemia (ET), only a few cases have been reported of blast crisis transformed into acute myeloid leukemia (AML) during a long-term course. Regarding risk factors for blast crisis, the involvement of genetic and chromosomal abnormalities has been found in addition to the clinical background [1]. We encountered a case of ET that progressed to AML approximately 9 years after the first diagnosis and then had a rapid outcome approximately 9 months after the AML diagnosis. Here, we report an interesting case of confirmed chromosome karyotype progression.

\section{Case Report}

A 60-year-old man had an increased platelet count in June 2008. Bone marrow examination was performed, and the blast ratio was $1.2 \%$ in the smear, and megakaryocyte proliferation was detected in the bone marrow biopsy (Fig. 1a). The chromosome karyotype was normal, and ET was diagnosed. The platelet count was controlled at $<60 \times 10^{4} / \mu \mathrm{L}$ by oral hydroxyurea (HU) and aspirin, but it decreased to $18 \times 10^{4} / \mu \mathrm{L}$ in November 2016. Considering bone marrow suppression due to $\mathrm{HU}$, the dose was reduced; however, the platelet count 


\section{Case Reports in Oncology}

Table 1. Laboratory data on admission

\begin{tabular}{l|l}
\hline Case Rep Oncol 2021;14:217-223 \\
\hline DOI: 10.1159/000512071 & $\begin{array}{l}\text { @ 2021 The Author(s). Published by S. Karger AG, Basel } \\
\text { www.karger.com/cro }\end{array}$ \\
\hline
\end{tabular}

Shimizu et al.: AML from ET with Deletion of Chromosome 7q and Trisomy 8

$\begin{array}{ll}\text { Complete blood count } & \\ \text { White blood cells } & 34.2 \times 10^{9} / \mathrm{L} \\ \quad \text { Blasts } & 40.5 \% \\ \text { Segmented } & 39.5 \% \\ \text { Eosinophils } & 0.0 \% \\ \text { Basophils } & 0.0 \% \\ \text { Monocytes } & 2.0 \% \\ \text { Lymphocytes } & 7.0 \% \\ \quad \text { Erythroblasts } & 2.0 \% \\ \text { Red blood cells } & 226 \times 10^{4} / \mu \mathrm{L} \\ \text { Hemoglobin } & 7.3 \mathrm{~g} / \mathrm{dL} \\ \text { Hematocrit } & 22.3 \% \\ \text { MCV } & 98.7 \% \\ \text { Platelets } & 3.3 \times 10^{4} / \mu \mathrm{L}\end{array}$

Biochemistry

AST 26 IU/L

ALT $15 \mathrm{IU} / \mathrm{L}$

CK $38 \mathrm{IU} / \mathrm{L}$

LD 1,318 IU/L

Total bilirubin $\quad 1.32 \mathrm{mg} / \mathrm{dL}$

BUN $14.0 \mathrm{mg} / \mathrm{dL}$

Creatinine $\quad 0.98 \mathrm{mg} / \mathrm{dL}$

Total protein $\quad 7.2 \mathrm{~g} / \mathrm{dL}$

Albumin $\quad 4.5 \mathrm{~g} / \mathrm{dL}$

Coagulation system

PT $14.2 \mathrm{~s}$

APTT $29.2 \mathrm{~s}$

Fibrinogen $293 \mathrm{mg} / \mathrm{dL}$

FDP $\quad 7.0 \mu \mathrm{g} / \mathrm{mL}$

\begin{tabular}{ll}
\hline Immunochemistry & \\
$\mathrm{CRP}$ & $0.88 \mathrm{mg} / \mathrm{dL}$ \\
$\mathrm{HBs}-\mathrm{Ag}$ & Negative \\
$\mathrm{HBs}-\mathrm{Ab}$ & Negative \\
$\mathrm{HCV}-\mathrm{Ab}$ & Negative \\
$\mathrm{HIV}-\mathrm{Ab}$ & Negative \\
$\mathrm{T}-\mathrm{SPOT}$ & Negative
\end{tabular}

continuously decreased. Bone marrow examination was performed; however, the dry tap and biopsy sample showed fibrosis (grade 1) (Fig. 1b). Therefore, the patient was diagnosed with secondary myelofibrosis (MF), and ruxolitinib (10 mg/day) was prescribed. However, the white blood cell and blast counts increased in the peripheral blood, resulting in AML diagnosis and hospital admission in June 2017. On examination, his Eastern Cooperative Oncology Group (ECOG) performance status was 1, the temperature $37.0^{\circ} \mathrm{C}$, blood pressure $117 / 56 \mathrm{~mm}$ $\mathrm{Hg}$, and pulse rate $89 \mathrm{bpm}$. His heart and respiratory sounds were normal. Palpation of the liver or spleen was negative. Palpation of superficial lymph nodes showed no abnormal findings. Rashes were found on the head, trunk, and upper limbs. Laboratory findings showed elevated white blood cell counts, anemia, and decreased platelet counts. Biochemical examination revealed a high level of lactate dehydrogenase (LD) (Table 1). Bone marrow examination showed a dry tap, and the blast ratio was $36.2 \%$ of nucleated cells (Table 2). In the smear, monotonous blast proliferation was observed (Fig. 1c, d). The blast cells were positive for myeloperoxidase staining (Fig. 1e) and for specific esterase staining (Fig. 1f). Flow cytometry analysis showed that the blast fraction of SSC ${ }^{\text {low }}-\mathrm{CD} 45^{\text {int }}$ was $\mathrm{CD} 33$ weakly positive,

\section{Karger's}




\section{Case Reports in Oncology}

Table 2. Results of bone marrow aspiration at admission

\begin{tabular}{l|l}
\hline Case Rep Oncol 2021;14:217-223 \\
\hline DOI: 10.1159/000512071 & $\begin{array}{l}\text { @ 2021 The Author(s). Published by S. Karger AG, Basel } \\
\text { www.karger.com/cro }\end{array}$ \\
\hline
\end{tabular}

Shimizu et al.: AML from ET with Deletion of Chromosome 7q and Trisomy 8

$\begin{array}{lc}\text { NCC } & 3.1 \times 10^{4} / \mu \mathrm{L} \\ \text { Megakaryocytes } & <3 / \mu \mathrm{L} \\ \text { M/E ratio } & 20.8 \\ \text { Erythroid cells } & 4.2 \% \\ \text { Blasts } & 36.2 \% \\ \text { Myeloblasts } & 3.3 \% \\ \text { Promyelocytes } & 2.2 \% \\ \text { Myelocytes } & 10.4 \% \\ \text { Metamyelocytes } & 4.4 \% \\ \text { Band cells } & 3.0 \% \\ \text { Segmented cells } & 31.0 \% \\ \text { Eosinophilic cells } & 0.0 \% \\ \text { Basophilic cells } & 0.0 \% \\ \text { Lymphocytes } & 7.8 \% \\ \text { Monocytes } & 0.8 \% \\ \text { Plasma cells } & 0.0 \%\end{array}$

CD13 positive, CD34 weakly positive, CD117 positive, and HLA-DR positive (Fig. 1g-k). Chromosome analysis (G-staining method) revealed the deletion of chromosome 7 long arm and chromosome 8 trisomy (Fig. 11). Based on the 2016 World Health Organization classification, he was diagnosed with AML-myelodysplasia-related changes.

Genetic testing revealed that he had an FLT3-ITD mutation. Combination therapy of daunorubicin $\left(40 \mathrm{mg} / \mathrm{m}^{2}\right.$, days $\left.1-3\right)$ and cytarabine (Ara-C; $100 \mathrm{mg} / \mathrm{m}^{2}$, days $\left.1-7\right)$ was initiated based on the induction regimen for elderly patients (GML200) (Fig. 2). Bone marrow examination after the induction therapy revealed an incomplete remission. Since his general condition was good, reinduction therapy was performed with the combination therapy of idarubicin (12 mg/m², days 1-3) and Ara-C (100 mg/m², days 1-7) based on the JALSG AML201 regimen [2]. However, after the first course of consolidation therapy, a uniformly proliferated blast population was confirmed by the bone marrow biopsy specimen and flow cytometry, and he was diagnosed as having relapsed. From January 2018, a triple V therapy was performed as salvage chemotherapy; however, the number of blasts in the peripheral blood rapidly increased (day 2: $90 / \mu \mathrm{L}$; day 30:56,182/ $\mu \mathrm{L}$ ). Therefore, we decided to choose palliative chemotherapy. In February 2018, gemutuzumab ozogamicin therapy $\left(9 \mathrm{mg} / \mathrm{m}^{2}\right.$ on days 1 and 15) [3] was started as a palliative chemotherapy. Laboratory findings (white blood cell count and LD) showed a temporary improvement; however, the number of blasts was still

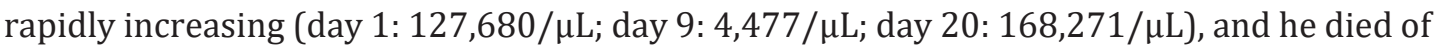
cerebral hemorrhage in March 2018.

The histopathological findings showed subarachnoid and intraparenchymal hemorrhages (Fig. 3a, b). Tumor cells invaded the cerebrum, brainstem, and cerebellum (Fig. 3b-d). In addition, bleeding was observed around the tumor infiltration in the cerebrum (Fig. 3b). Immunohistochemical examination of CD33 expression on tumor cells during spleen biopsy showed diffuse expression, which was consistent with the clinical course of resistance to gemutuzumab ozogamicin therapy (Fig. 3e).

\section{Discussion}

ET can be transformed into MF and AML when the disease duration is long. The transformation rate is $0.8 \%$ in 10 years and $9.3 \%$ in 15 years into MF and $0.7 \%$ in 10 years and $2.1 \%$ in 15 years into AML [4]. Since the frequency of transformation into MF and AMF is low, the ET prognosis is expected to be the same as in healthy individuals [5]. However, in our case, 


\section{Case Reports in Oncology}

\begin{tabular}{l|l}
\hline Case Rep Oncol 2021;14:217-223 \\
\hline DOI: 10.1159/000512071 & $\begin{array}{l}\text { ○ 2021 The Author(s). Published by S. Karger AG, Basel } \\
\text { www.karger.com/cro }\end{array}$ \\
\hline
\end{tabular}

Shimizu et al.: AML from ET with Deletion of Chromosome 7q and Trisomy 8

Fig. 2. Outline of the clinical course of our patient. Essential thrombocythemia (ET) progressed to acute myeloid leukemia (AML) via myelofibrosis (MF) in our case. The timing of chemotherapy and bone marrow tests is shown. (1) Daunorubicin (DNR) + cytarabine (Ara-C); (2) idarubicin + Ara-C; 3 mitoxantrone + Ara-C; (4) DNR + Ara-C; (5) A triple V; and 6) gemtuzumab ozogamicin. Note that the interval of laboratory data shown on this figure is 1 month. Some variables lacked data, and daily changes in laboratory data during chemotherapy are not precisely reflected in this figure. WBC, white blood cell count; LD, lactate dehydrogenase; Plts, platelet count.
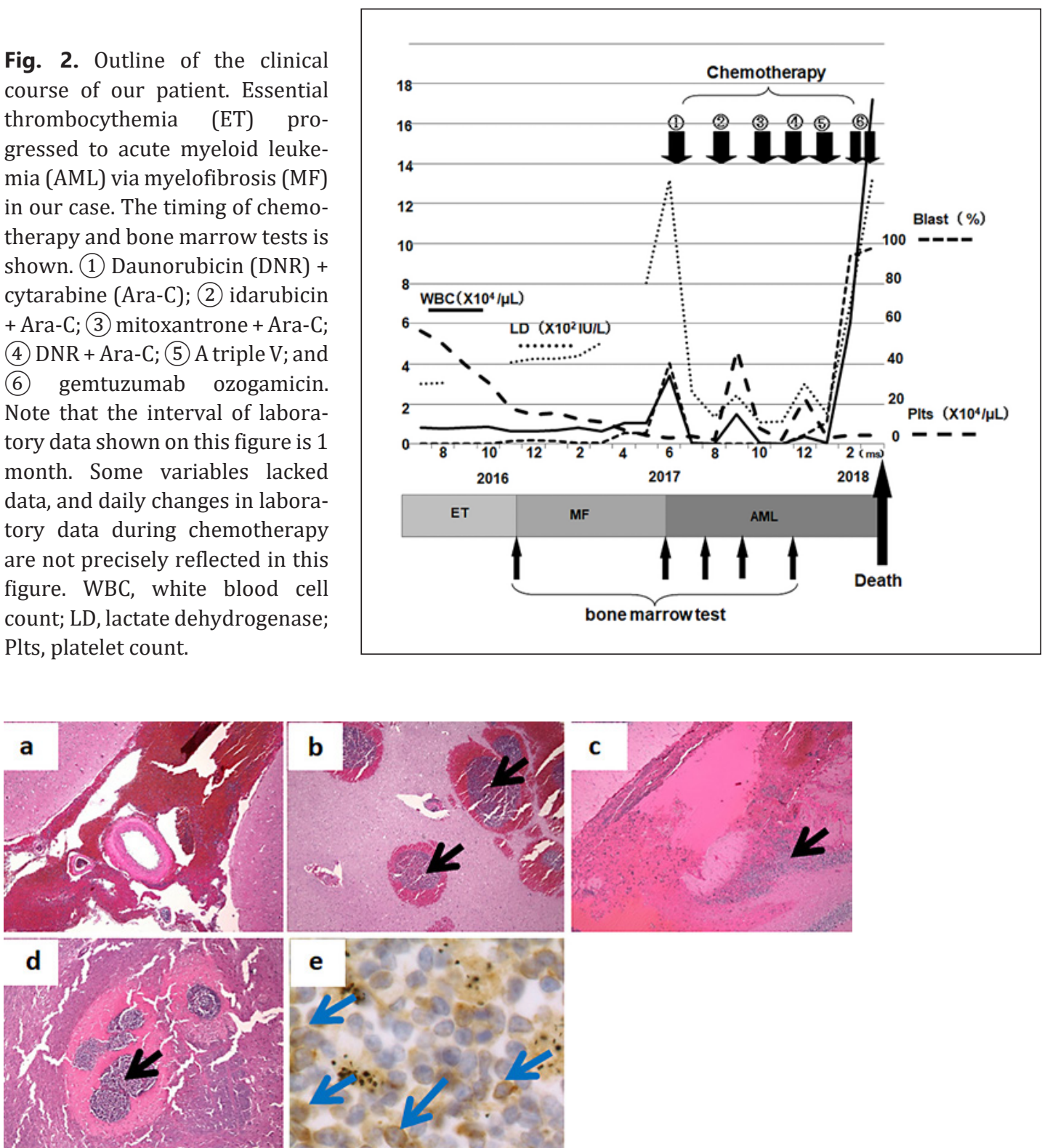

Fig. 3. Cerebral hemorrhage and tumor infiltration revealed by autopsy. a Subarachnoid space. b Brain parenchyma. c Cerebellum. d Brainstem. e Anti-CD33 antibody staining of an autopsy specimen of the spleen. Black arrows in $\mathbf{b}-\mathbf{d}$ indicate tumor cells infiltrating the brain. Blue arrows in e indicate CD33-positive cells in the splenic specimen. CD33, cluster of differentiation 33.

ET had progressed to AML in 9 years, and the prognosis was very poor. Risk factors for ET transformation into AML include morphology of bone marrow fibrosis, thrombocytosis $\left(\geq 100 \times 10^{4} / \mu \mathrm{L}\right)$, history of thrombosis [6], increase in white blood cell count $(\geq 15,000 / \mu \mathrm{L})$, anemia [6], and older age ( $\geq 60$ years) [7]. Genetic abnormalities such as $p 53$ [8] and RUNX1 mutations [9] have been reported. Regarding the karyotype, a SNP analysis of the chromosomal changes involved in leukocytosis in myeloproliferative tumors and compared with chronic-stage myeloproliferative tumors showed that loss of heterozygosity without alteration of the chromosome 7 copy number and involvement of chromosome 8 trisomy was 
involved in leukocytosis [10]. In our case, no risk factor for leukocytosis was detected at the time of ET diagnosis except older age (60 years); however, in the time course of 9 years, deletion of the long arm of chromosome 7 and additional chromosome 8 abnormality occurred. This strongly suggests that the leukemia progression in our case involved deletion of the chromosome 7 long arm and additional chromosome 8 abnormalities.

In a multivariate analysis of 183 ET cases performed by the Mayo Clinic, the presence of mutations in EZH2 near the end of the chromosome 7 (7q36.1) long arm was considered to be a poor prognostic factor for leukemia transformation [11]. Since most of the chromosome 7 long arm was deleted at the onset of AML in our case, a heterozygous deletion of EZH2 was suspected to have been involved in the gene-level pathogenesis in our case.

This patient rapidly relapsed after reinduction chemotherapy and died of cerebral hemorrhage during palliative chemotherapy. Since infiltration of tumor cells into the brain parenchyma was observed on pathological autopsy, the central nervous system infiltration of the tumor might have been a risk factor that resulted in cerebral hemorrhage. High white blood cell counts and vascular elasticity changes due to chemotherapy have been reported as risk factors for cerebral hemorrhage in AML $[12,13]$. A recent retrospective analysis suggested that increased LD and karyotype abnormalities such as trisomy 8 and FLT3-ITD mutation were risk factors for central nervous system recurrence $[14,15]$. In our case, trisomy 8 and FLT3-ITD mutation were found at the onset of AML, which may have affected the invasion of the central nervous system.

\section{Conclusions}

Deletion of the chromosome 7 long arm, acquisition of chromosome 8 trisomy, and FLT3-ITD mutation may have been involved in the transition from ET to AML and the invasion of the central nervous system in our case. Therefore, the risk of leukocytosis in ET should be identified, and appropriate treatment should be selected, including palliative therapy for the group of elderly patients with a poor prognosis.

\section{Acknowledgements}

We thank the patient and his family for this work.

\section{Statement of Ethics}

Written informed consent was obtained from the patient's family for publication of this case report and any accompanying images.

\section{Conflict of Interest Statement}

The authors have no conflict of interest to declare.

\section{Funding Sources}

This research did not receive grants from any funding agency in the public, commercial, or not-for-profit sectors.

\section{Karger'}




\section{Case Reports in Oncology}

\begin{tabular}{l|l}
\hline Case Rep Oncol 2021;14:217-223 \\
\hline DOI: 10.1159/000512071 & $\begin{array}{l}\text { @ 2021 The Author(s). Published by S. Karger AG, Basel } \\
\text { www.karger.com/cro }\end{array}$ \\
\hline
\end{tabular}

Shimizu et al.: AML from ET with Deletion of Chromosome $7 q$ and Trisomy 8

\section{Author Contributions}

A.S., K.T., and T.S. wrote the manuscript; A.S., K.T., S.O., T.I., and T.S. treated the patient and acquired data; H.H. and K.M. prepared and analyzed the bone marrow samples; Y.Y. prepared and analyzed the autopsy samples.

\section{References}

1 Cerquozzi S, Tefferi A. Blast transformation and fibrotic progression in polycythemia vera and essential thrombocythemia: a literature review of incidence and risk factors. Blood Cancer J. 2015 Nov 13;5(11):e36675.

2 Miyawaki S, Ohtake S, Fujisawa S, Kiyoi H, Shinagawa K, Usui N, et al. A randomized comparison of 4 courses of standard-dose multiagent chemotherapy versus 3 courses of high-dose cytarabine alone in postremission therapy for acute myeloid leukemia in adults: the JALSG AML201 Study. Blood. 2011 Feb;117(8) 117):236672.

3 Larson RA, Sievers EL, Stadtmauer EA, Löwenberg B, Estey EH, Dombret H, et al. Final report of the efficacy and safety of gemtuzumab ozogamicin (Mylotarg) in patients with CD33-positive acute myeloid leukemia in first recurrence. Cancer. 2005 Oct;104(7):1442-52.

4 Barbui T, Thiele J, Passamonti F, Rumi E, Boveri E, Ruggeri M, et al. Survival and disease progression in essential thrombocythemia are significantly influenced by accurate morphologic diagnosis: an international study. J Clin Oncol. 2011 Aug;29(23):3179-84.

5 Japanese Society of Hematology. Practical guidelines for hematological malignancies. 2018. p. 89-100.

6 Abdulkarim K, Ridell B, Johansson P, Kutti J, Safai-Kutti S, Andréasson B. The impact of peripheral blood values and bone marrow findings on prognosis for patients with essential thrombocythemia and polycythemia vera. Eur J Haematol. 2011 Feb;86(2):148-55.

7 Pasaamonti F, Rumi E, Arcaini L, Boveri E, Elena C, Pietra D, et al. Prognostic factors for thrombosis, myelofibrosis, and leukemia in essential thrombocythemia: a study of 605 patients. Haematologica. 2008 Nov; 93(11): $1645-51$.

8 Harutyunyan A, Klampfl T, Cazzola M, Kralovics R. p53 lesions in leukemic transformation. N Engl J Med. 2011 Feb;364(5):488-90.

9 Vainchenker W, Delhommeau F, Constantinescu SN, Bernard OA. New mutations and pathogenesis of myeloproliferative neoplasms. Blood. 2011 Aug;118(7):1723-35.

10 Thoennissen NH, Krug UO, Lee DH, Kawamata N, Iwanski GB, Lasho T, et al. Prevalence and prognostic impact of allelic imbalances associated with leukemic transformation of Philadelphia chromosome-negative myeloproliferative neoplasms. Blood. 2010 Apr;115(14):2882-90.

11 Tefferi A, Lasho TL, Guglielmelli P, Finke CM, Rotunno G, Elala Y, et al. Targeted deep sequencing in polycythemia vera and essential thrombocythemia. Blood Adv. 2016 Nov;1(1):21-30.

12 Würthner JU, Köhler G, Behringer D, Lindemann A, Mertelsmann R, Lübbert M. Leukostasis followed by hemorrhage complicating the initiation of chemotherapy in patients with acute myeloid leukemia and hyperleukocytosis: a clinicopathologic report of four cases. Cancer. 1999 Jan;85(2):368-74.

13 Lam WA, Rosenbluth MJ, Fletcher DA. Chemotherapy exposure increases leukemia cell stiffness. Blood. 2007 Apr;109(8):3505-8.

14 Jabbour E, Guastad Daver N, Short NJ, Huang X, Chen HC, Maiti A, et al. Factors associated with risk of central nervous system relapse in patients with non-core binding factor acute myeloid leukemia. Am J Hematol. 2017 Sep;92(9):924-8.

15 Shihadeh F, Reed V, Faderl S, Medeiros LJ, Mazloom A, Hadziahmetovic M, et al. Cytogenetic profile of patients with acute myeloid leukemia and central nervous system disease. Cancer. 2012 Jan;118(1):112-7. 